\title{
Density and Strength of Mortar Made with the Mixture of Wood Ash, Crushed Gneiss and River Sand as Fine Aggregate
}

\author{
Mambou Ngueyep Luc Leroy ${ }^{1,2 *}$, Keyangue Tchouata Jules Hermann², \\ Atangana Nkene Elise Rose ${ }^{3,4}$, Ndop Joseph ${ }^{1,3}$, Fotseu Miyo Christian Dupont ${ }^{2}$, \\ Ndjaka Jean-Marie Bienvenu' ${ }^{1}$ \\ ${ }^{1}$ Laboratory of Material Sciences, Department of Physics, Faculty of Sciences, University of Yaoundé 1, Yaoundé, \\ Cameroon \\ ${ }^{2}$ School of Geology and Mining Engineering, University of Ngaoundéré, Meiganga, Cameroon \\ ${ }^{3}$ Douala Institute of Technology, Douala, Cameroon \\ ${ }^{4}$ Department of Physics, Faculty of Sciences, University of Douala, Douala, Cameroon \\ Email: ^mamboulucleroy@gmail.com
}

How to cite this paper: Leroy, M.N.L., Hermann, K.T.J., Rose, A.N.E., Joseph, N., Dupont, F.M.C. and Bienvenu, N.J.-M. (2018) Density and Strength of Mortar Made with the Mixture of Wood Ash, Crushed Gneiss and River Sand as Fine Aggregate. Journal of Materials Science and Chemical Engineering, 6, 109-120. https://doi.org/10.4236/msce.2018.64012

Received: February 13, 2018

Accepted: April 24, 2018

Published: April 27, 2018

Copyright (c) 2018 by authors and Scientific Research Publishing Inc. This work is licensed under the Creative Commons Attribution International License (CC BY 4.0).

http://creativecommons.org/licenses/by/4.0/ (c) (i)

\begin{abstract}
The main purpose of this paper is to study the feasibility of using wood bottom ash to partially replace natural fine aggregate or crushed gneiss sand in the manufacturing of mortars. The experiment uses wood ash as fine aggregates, which passes through $5 \mathrm{~mm}$ sieve, in proportions of $5 \%, 10 \%, 15 \%, 20 \%$ and $25 \%$ by weight to replace partially river sand and crushed gneiss, and the both sand of the same size as the aggregate respectively. Experimental results show that density of mortar and the compressive strength of mortar decrease globally with the increase in wood ash content. At 56 days, and for all replacements with wood ash, compressive strengths values of mortar obtained with the mixture of wood ash and river sand is greater than $20 \mathrm{MPa}$, which is not the case for mortar made with crushed gneiss and wood ash. Moreover, for $5 \%$ of replacement with wood ash, compressive strengths of mortar obtained with the mixture of wood ash and river sand and the mixture of wood ash and crushed gneiss are respectively $37 \mathrm{MPa}$ and $32 \mathrm{MPa}$ at 56 days. These values satisfied the strength requirements. Hence, $5 \%$ replacement of crushed gneiss with wood ash is suggested and could be benefit for mortar. In addition, the replacement of sand by wood ash is preferable with river sand which contains fewer fines than crushed gneiss. The compressive strength of mortar with $25 \%$ wood ash + river sand could be suitable.
\end{abstract}

\section{Keywords}

Wood Bottom Ash, River Sand, Crushed Gneiss, Mortar, Compressive 
Strength, Density

\section{Introduction}

The research intended to use recycled waste and transform the "waste" into "resources", and put them into construction materials to meet the concepts of "green construction", "environmental protection" and "recycling resource" [1]. According to the European Waste Catalogue and hazardous residues list [2], both bottom ash and fly ash from combustion of untreated wood are classified as non-hazardous wastes. Wood ash (WA) is the residue from the burning of wood and wood products (chips, saw dust, bark, etc.). Physical and chemical properties of WA vary significantly depending on many factors: species of wood, method of combustion including temperature, other fuels co-combusted with the wood and method of WA collection [3]. However, in order to better understand the application of WA in the manufacturing of concrete or cement, many studies have been dealt with partial replacement of Wood Ash with Ordinary Portland Cement [3]-[12]. These studies discuss the effects of WA on the strength, workability, density, thermal insulation, etc. of concretes and mortars. Globally, it was found that the wood ash could be successfully incorporated into the conventional concrete. In most cases, the wood ash addition helped to increase the early-age compressive strength of concrete [7]. Wood ash at replacement percentage up to $10 \%$ of the weight of binder can be successfully used as additive in place of cement to produce structure grade concrete [7] [8]. Utilization of wood ash as a partial substitution for cement is one of the promising methods to increase the strength and thermal insulation for cement blocks [9] [10]. Wood ash chemical characteristics differ with species of wood but mostly contain lime and silica and thus can be used as cement replacing material [7]-[12].

Recently some investigations have been done on wood ash as sand replacement; some of them are presented in following.

In 2014, Min-Jen Yang et al. [5], studied the effects on Strengths of Cement Mortar When Using Incinerator Bottom Ash as Fine Aggregate. Their study shows that, the incinerator bottom ash (IBA) fine aggregates mortar can only reach $60 \%-70 \%$ of the compressive strength of natural fine aggregates mortar. In terms of compressive strength versus unit weight, the lightweight effect of cement mortar or cement related product by using IBA fine aggregates is unable to compensate the lost in the strength.

In 2016, Lisbeth M. et al. [4], investigated the wood ash used as partial replacement of sand and/or cement in mortar. The overall aim of their work was to evaluate the influence from the differences in ash characteristics to the properties of the mortar samples. One of the ashes had a very high Loss on ignition (LOI) and using this ash resulted in the lowest compressive strength both when used as partly sand and cement replacement. 
Decreasing strength with increasing percentage of WA was observed. Washing the ash in water to eliminate the soluble fraction leads to the decreasing of the compressive strength of the mortar slightly compared to an unwashed ash. At higher percentages extra water is needed to keep an acceptable workability.

Recently in 2017, Amir Shafi Batt and Anshul Garg [6] investigated the possibility of incorporation of wood ash in combination with ordinary Portland cement while using it for various structural works. The Optimum results were obtained at $15 \%$ replacement of wood ash with ordinary Portland cement. They also conclude that foundry Sand is used as fine aggregate to obtain efficient results.

In 2017 K. V. Boobala Krishnan et al. [7], investigate experimentally the behavior and strength of concrete by replacing cement with wood ash and fine aggregate with wood powder. Cement was partially replaced by $5 \%$ of Wood Ash and Fine aggregate is partially replaced by $5 \%, 10 \%$ and $15 \%$ of wood powder. Their results showed that the replacement of fine aggregate by wooden powder in concrete makes the structure light in weight. They concluded that the Use of wood ash and wood powder in concrete is an interesting possibility for the conservation of natural resources.

However, all these previous works cited doesn't study the possibility of using the mixture of wood ash and crushed gneiss as fine aggregate in the manufacturing of mortars. The main purpose of this paper is to study the feasibility of using the WA fine aggregate to replace natural or crushed gneiss fine aggregate in the cement mortar production.

In this paper we analyze the chemical and physical properties of wood ash from artisanal bakery, the compressive strength and density of mortars manufactured with mixture of wood ash and river sand or crushed gneiss through laboratory experiments. We investigate the possibility of incorporation in alluvial sand or crushed gneiss as fine aggregate in mortar production. Wood ash from artisanal is choosing because it receives any kind of wood.

This document is organized as follows. Material and Experimental methods are presented in Section 1. Section 2 is devoted to experimental results and discussion. Finally, the conclusion is given in Section 4 .

\section{Material and Experimental Methods}

\subsection{Materials}

\subsubsection{Wood Ash (WA)}

Wood ash used is coming from an artisanal bakery from Mimboman-Yaounde. The combustion of wood is done to produce the heat necessary for cooking. This ash is sampled by dry way then sifter. The quantity used in this study has been sampled the same day, under same condition of temperature, with a same material and with characteristic sampling technique. WA was passed through BS sieve $0.05 \mathrm{~mm}$ by automatic sieving. Wood ash has been prepared at constant water content. The combustion parameters remain constant in the bakery. The 
amount of wood ash produced at the bakery level is important.

\subsubsection{Cement}

The cements used in our project are a cement Portland composed C.P.J NC CEM II/B-P 42,5R according to the norm NC 234: 2009-06, coming from the cement factory CIMENCAM of Figuil (North of Cameroon). The Table 1 summarizes some utilized cement physical characteristics.

\subsubsection{Aggregates}

Sand is the constituent of the granular skeleton which has more impact on the mortar. It plays a primordial role while reducing the bulky variations, the free heats and the flat price of the concretes. It must be clean and must not contain any harmful elements.

An alluvial sand coming from Sanaga River and crushed gneiss coming from Eloumden Quarry were used in this study as fine aggregate. The Table 1 presents the physical properties those sands.

Table 2 shows that crushed gneiss has the highest density followed by alluvial sand and the wood ash. Sanaga sand has the highest fineness moduli. The wood ash is predominantly fine-grained. The fineness modulus is even smaller than sand is rich in fine elements. For the Equivalent of sand test, Sanaga sand have the highest equivalent sand. It means that Sanaga sand contains less fine elements and clay particles than crushed gneiss.

\subsection{Methods}

\subsubsection{Mix and Casting of Mortar}

In this study, nine different proportions of mortar mixes (WA replacement of $5 \%, 10 \%, 15 \%, 20 \%$ and $25 \%$ ) including the control mixture were prepared with a water to binder ratio of $\mathrm{W} / \mathrm{C}=0.475$ and $\mathrm{W} / \mathrm{C}=0.4$ respectively for crushed

Table 1. Physical properties of cement.

\begin{tabular}{cc}
\hline Properties & C.P.J NC CEM II/B-P 42,5R \\
\hline Initial setting time (min) & 140 \\
Final setting time (min) & 360 \\
Mass specific & $3.12 \mathrm{~g} / \mathrm{cm}^{3}$ \\
Blaine Specific surface area & $3425 \mathrm{~cm}^{2} / \mathrm{g}$ \\
Consistency & $30 \%$ \\
\hline
\end{tabular}

Table 2. Physical properties of sand and WA.

\begin{tabular}{cccc}
\hline Physicals properties & Sanaga sand & crushed gneiss & WA \\
\hline Compacted bluk density $\left(\mathrm{g} / \mathrm{cm}^{3}\right)$ & 2.8 & 5.4 & 0.8 \\
Non-compacted bluk density $\left(\mathrm{g} / \mathrm{cm}^{3}\right)$ & 1.7 & 3.5 & 1.1 \\
Equivalent of Sand: ES at Piston $(\%)$ & 73.81 & 68.80 & - \\
Fineness moduli & 3.01 & 2.5 & 6.35 \\
Coefficient of Uniformity & 4 & 8 & 0.62 \\
Coefficient of Curvature & 1 & 0.5 & \\
\hline
\end{tabular}


gneiss and river sand. Specimens of Mortars were formulated into two groups of specimen (mortar based on crushed sand + wood ash and mortar based on river sand + wood ash). For each replacement percentage mortar was molded into $5 \times$ $5 \times 5 \mathrm{~cm}$ cubic blocks, and then submitted to compressive test and density test on 28 days. After casting all, the specimens were stored at room temperature and then de-molded after $24 \mathrm{~h}$, and placed into a water-curing tank with a temperature of $23^{\circ} \mathrm{C}-27^{\circ} \mathrm{C}$.

For each replacement percentage two specimens were casted for 7 days, three specimens were casted for 28 days test and two specimens were casted for 56 days test. The average result is reported in the paper.

\subsubsection{Characterisation of Ash, Cement and Sand}

Characterisation and extraction experiments were made with dried WA $\left(105^{\circ} \mathrm{C}\right.$, 24 hours). Concentrations of mains oxides $\mathrm{SiO}_{2}, \mathrm{Al}_{2} \mathrm{O}_{3}, \mathrm{Fe}_{2} \mathrm{O}_{3}, \mathrm{CaO}, \mathrm{MgO}, \mathrm{TiO}_{2}$, $\mathrm{K}_{2} \mathrm{O}, \mathrm{SO}_{3}$ and $\mathrm{Na}_{2} \mathrm{O}$ were measured by X-ray Fluorescence (XRF) in accordance with ref. [13]. Ash pH was measured by suspending $10.0 \mathrm{~g}$ ash in $25 \mathrm{~mL}$ of distilled water. After 1 hour agitation, the $\mathrm{pH}$ was measured directly in suspension with a $\mathrm{pH}$ electrode. Loss on ignition (LOI) was found after 30 minutes at $550^{\circ} \mathrm{C}$. Water content was measured as weight loss after 24 hours at $105^{\circ} \mathrm{C}$ (calculated as weight loss over the weight of the wet sample). Solubility of ash in water was also evaluated: $50.0 \mathrm{~g}$ ash suspended in $500 \mathrm{~mL}$ of distilled water and agitated for $1 \mathrm{~min}$. After settling the water was decanted. New $500 \mathrm{~mL}$ distilled water was added. The ash is washed three times. Finally the suspension is filtered and the ash is dried and weighed. Specific gravity, Blaine specific surface area and bulk density of both WAs were found. Particles size distribution is determined by automatic sieving.

Consistencies, initial and final setting time of cement were found on the cement pastes [14]. Mixtures were made with mortar mixer ELE international in according with [15]. Mass specific and Blaine Specific surface area of cement are determined with "Le Chatelier and Air-Permeability Apparatus" in conformity with ref [16] [17].

Fineness, Coefficient of uniformity and Coefficient of Curvature have been calculated using particles size distribution analysis results [18]. Bulk density and Equivalent of Sand have determined according to ref [19] [20].

\subsubsection{Mortar Cubes Compressive Strength and Density Measurements} Mortar cubes preparation and compressive strength measurement were made according to ref [15]-[21]. In this survey, density of mortars made with WA as partial replacement of sand has been examined. Density measure has been done on three test-cubes. The average of the three values is recorded like being the density. The volume of the test-cube has been fixed at $\mathrm{V}=125 \mathrm{~cm}^{3}$.

\section{Results and Discussions}

\subsection{Characterisation of the Ash}

The results from the characterization of WA are presented in Table 3. 
Table 3. Characteristics of WA.

\begin{tabular}{|c|c|}
\hline Constituent & Of WA \\
\hline \multicolumn{2}{|c|}{ Physicals properties } \\
\hline Specific gravity & 2.96 \\
\hline Blaine specific surface area, $\mathrm{cm}^{2} / \mathrm{g}$ & 4013 \\
\hline non-compacted bulk density $\mathrm{g} / \mathrm{cm}^{3}$ & $0.89^{(*)}$ \\
\hline compacted bulk density $\mathrm{g} / \mathrm{cm}^{3}$ & $1.1^{(* *)}$ \\
\hline \multicolumn{2}{|c|}{ Chemical composition \% } \\
\hline $\mathrm{SiO}_{2}$ & 50.38 \\
\hline $\mathrm{Al}_{2} \mathrm{O}_{3}$ & 8.45 \\
\hline $\mathrm{Fe}_{2} \mathrm{O}_{3}$ & 1.65 \\
\hline $\mathrm{SiO}_{2}+\mathrm{Al}_{2} \mathrm{O}_{3}+\mathrm{Fe}_{2} \mathrm{O}_{3}$ & 60.48 \\
\hline $\mathrm{CaO}$ & 13.02 \\
\hline $\mathrm{MgO}$ & 1.25 \\
\hline $\mathrm{SO}_{3}$ & 2.03 \\
\hline $\mathrm{TiO}_{2}$ & 0.17 \\
\hline $\mathrm{K}_{2} \mathrm{O}$ & 12.61 \\
\hline $\mathrm{Na}_{2} \mathrm{O}$ & 1.7 \\
\hline $\mathrm{Na}_{2} \mathrm{O}$ eq ${ }^{(\mathrm{a})}$ & 10.00 \\
\hline LOI & 8.42 \\
\hline $\mathrm{pH}$ & 12.35 \\
\hline Solubility (\%) & 12 \\
\hline Water content $(\%)$ & 2.1 \\
\hline
\end{tabular}

The total percentage composition of Iron oxide $\left(\mathrm{Fe}_{2} \mathrm{O}_{3}=1.65 \%\right)$, aluminium oxide $\left(\mathrm{Al}_{2} \mathrm{O}_{3}=8.45 \%\right)$ and silicon dioxide $\left(\mathrm{SiO}_{2}=50.38 \%\right)$ was found to be $60.48 \%$.

The Loss on ignition obtained was $8.42 \%$. This means that the wood ash contain appreciable amount of un-burnt carbon. The un-burnt carbon presence serves as filler to the mixture.

The alkali content $\left(\mathrm{Na}_{2} \mathrm{O}\right.$ eq) was found to be $10.00 \%$. This value is higher than the maximum alkali content of $1.5 \%$ required for pozzolana [4]. The alkali content is important when the wood ash is used with reactive aggregate [5]. Wood ash will not be suitable for construction work where reactive aggregate is used [5]. The total soluble fraction of the WA is $12 \%$.

The $\mathrm{pH}$ (12.35) of the WA is high showing that hydroxides are leached $(\mathrm{pH}$ is measured in a suspension of WA in distilled water). The specific gravity is 2.96 .

The Blaine specific surface is $4013 \mathrm{~cm}^{2} / \mathrm{g}$ and bulk density of WA was found to be 1.1 and $0.89 \mathrm{~g} / \mathrm{cm}^{3}$ respectively for apparent and non-apparent ones.

\subsection{Particles Size Distribution and Geotechnical Properties}

Figure 1 presents particles size distribution of WA, WA curve is distant of the 


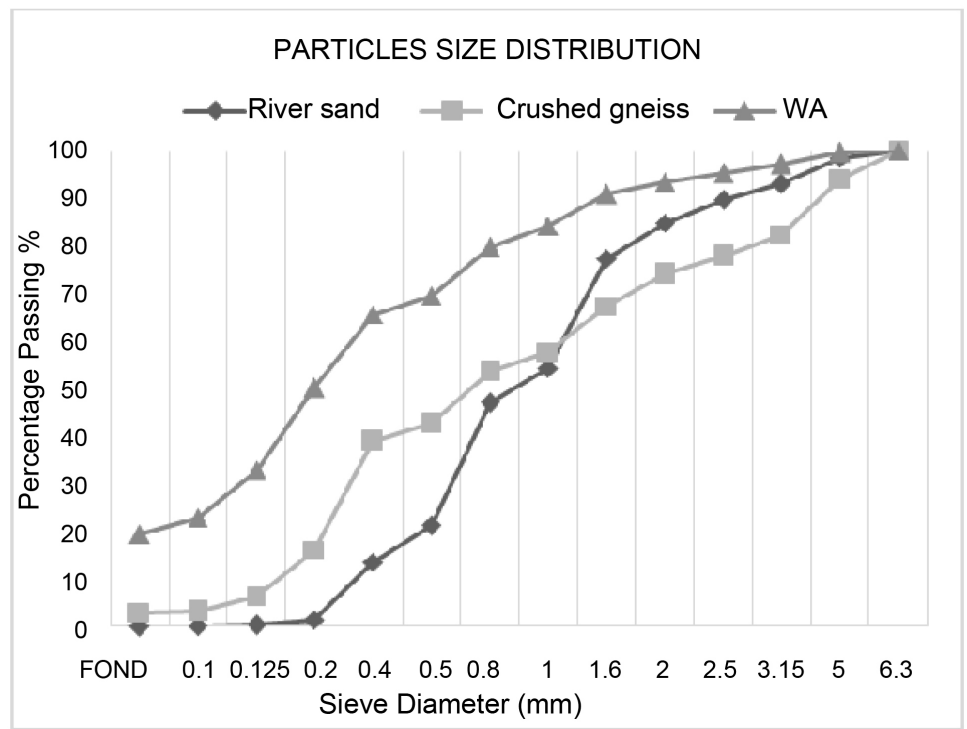

Figure 1. Particles size distribution curve of sands and WA.

others, which show an irregular size distribution. Geotechnical properties of WA are shown in Table 2. Finesse Modulus value is 1.7. This value confirms that WA is a very fine aggregate. Coefficient of Uniformity value is 6.35 characteristic of a spread granulometric distribution. These properties of WA prove that it contains in majority fine element and don't respect standard specification for sand used in mortar or concrete recommend in ASTM C 778. However it can be used as mixture with the sand which contains less percentage of fines.

\subsection{Compressive Strength Test}

Figure 2 and Figure 3 show the result for the compressive strength mortars at 7 , 28 and 56 days respectively made with river sand + WA and crushed gneiss sand + WA. These figures show the decrease in the compressive strength with an increasing amount of ash. The Decreasing of strength with an increasing of the percentage of WA is in agreement with literature; see e.g. [4]. It may be related to the high LOI of WA (about $8 \%$, Table 4) as the organic part (expressed as LOI) will not contribute to the compressive strength, but on the contrary the organic matter may add to spaces without strength [22]. However in Figure 2, the lowest value of strength is obtained with the replacement of $20 \%$ then it goes back up for $25 \%$ replacement. Due to the fact that WA presents pozzolanic properties, beyond $20 \%$ of wood ash, quantity of wood ash could be sufficient for pozzolanic reaction and free lime from cement could interact with wood ash. Then new formed CSH bonds could increase the strength of the mortar.

In Figure 2, the compressive strength of control mortar made with river sand (100\% of river sand as fine aggregate) is $23 \mathrm{MPa}, 28 \mathrm{MPa}$ and $47 \mathrm{MPa}$ respectively at 7 days, 28 days and 56 days. At $5 \%$ of replacement, the compressive strength of mortar is $17 \mathrm{MPa}, 24 \mathrm{MPa}$ and $37 \mathrm{MPa}$ respectively at 7 days, 28 days and 56 days. These values represent the loss in strength of $26 \%, 14 \%$ and $21 \%$ respectively at 7 days, 28 days and 56 days. 


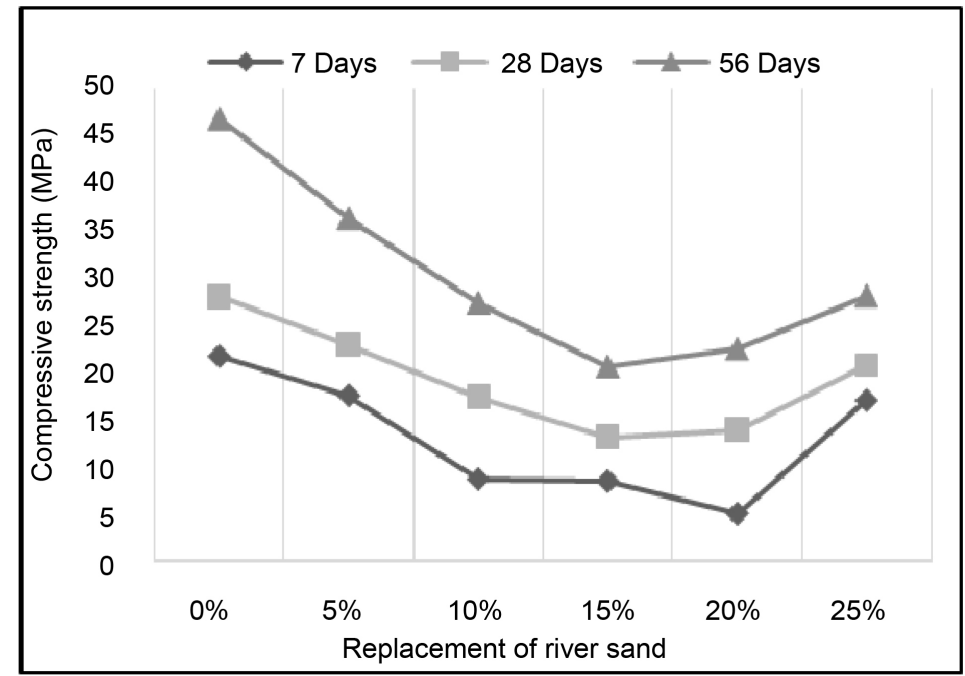

Figure 2. Compressive strength of mortar (river sand + WA with $\mathrm{C} / \mathrm{S}=$ $1 / 3)$ at 7,28 and 56 days.

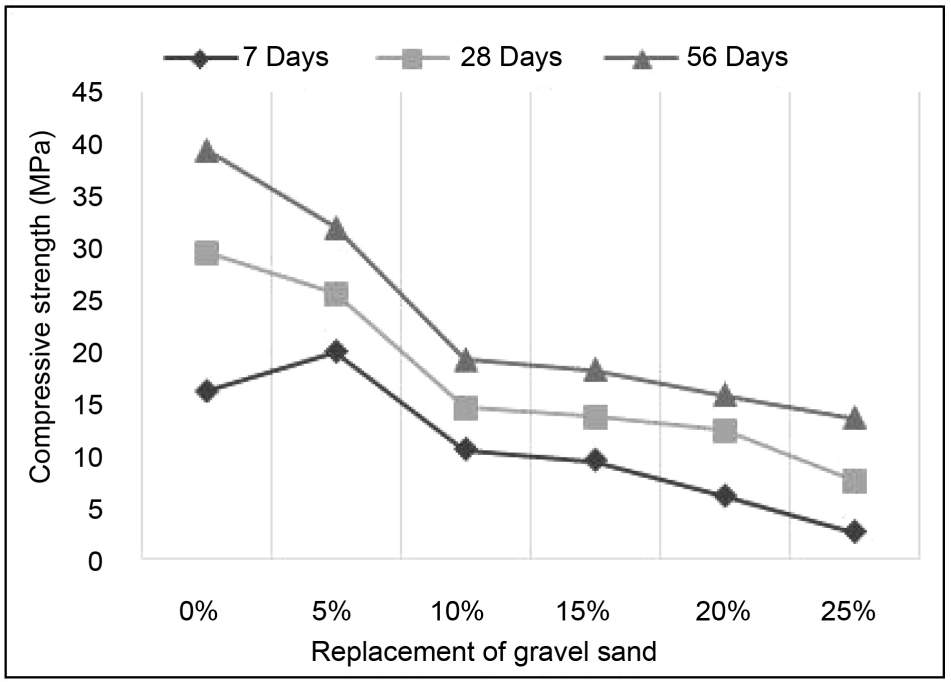

Figure 3. Compressive strength (crushed gneiss sand with $\mathrm{C} / \mathrm{S}=1 / 3$ ) at 7,28 and 56 days.

Table 4. Proportions of mortar mixes.

\begin{tabular}{cccccccc}
\hline Sand & Composition (g) & $0 \%$ & $5 \%$ & $10 \%$ & $15 \%$ & $20 \%$ & $25 \%$ \\
\hline $\begin{array}{c}\text { River sand } \\
\text { \& }\end{array}$ & Cement (g) & 494 & 494 & 494 & 494 & 494 & 494 \\
$\begin{array}{c}\text { Crushed } \\
\text { gneiss }\end{array}$ & WA (g) & 0 & 68 & 136 & 204 & 271 & 339 \\
$\begin{array}{c}\text { River sand } \\
\text { Crushed } \\
\text { Gneiss }\end{array}$ & Water (W/C = 0.4$)(\mathrm{g})$ & 198 & 200 & 202 & 204 & 206 & 210 \\
\hline
\end{tabular}

At $25 \%$ of replacement, the compressive strength of mortar is $16 \mathrm{MPa}, 21 \mathrm{MPa}$ and $27.5 \mathrm{MPa}$ respectively at 7 days, 28 days and 56 days. 
These values represent the loss in strength of $22 \%, 27 \%$ and $41 \%$ respectively at 7 days, 28 days and 56 days. However at 7 and 28 days of age, it is noted that the strength variance values between $5 \%$ and $25 \%$ of replacement is weak. Economic and environmental benefits could be obtained with $25 \%$ of replacement.

In Figure 3, it is noted that the compressive strength of control mortar made with crushed sand ( $100 \%$ of crushed gneiss sand as fine aggregate) is $16 \mathrm{MPa}, 29$ $\mathrm{MPa}$ and $38 \mathrm{MPa}$ respectively at 7 days, 28 days and 56 days. At $5 \%$ of replacement, the compressive strength of mortar is $20 \mathrm{MPa}, 25 \mathrm{MPa}$ and $32.5 \mathrm{MPa}$ respectively at 7 days, 28 days and 56 days. It is noted that the increase in strength of $25 \%$, at 7 days, and the loss in strength of $14 \%$ and $14.5 \%$ respectively 28 days and 56 days.

At $25 \%$ of replacement, the compressive strength of mortar is $3 \mathrm{MPa}, 7 \mathrm{MPa}$ and $14.5 \mathrm{MPa}$ respectively at 7 days, 28 days and 56 days. These values represent the loss in strength of $81 \%, 76 \%$ and $64 \%$ respectively at 7 days, 28 days and 56 days.

\subsection{Comparative Analysis between River Sand + WA and Crushed Gneiss + WA as Fine Aggregate in Mortar}

Figure 4 shows a comparison at 56 days of compressive strength of mortar cubes with river sand + WA and crushed gneiss + WA. We can note that the mortar made with river sand + WA has the highest compressive strength. It is important to note that at 56 days, above $15 \%$ of replacement, compressive strength of mortar made with river sand + WA increase, which is not the case for crushed gneiss one. At 56 days, and for all replacement with wood ash, the compressive strengths values of mortar obtained with the mixture of wood ash and river sand is greater than $20 \mathrm{MPa}$, which is not the case for mortar made with crushed gneiss and wood ash. Moreover, for $5 \%$ of replacement with wood ash, compressive strengths of mortar obtained with the mixture of wood ash and river sand

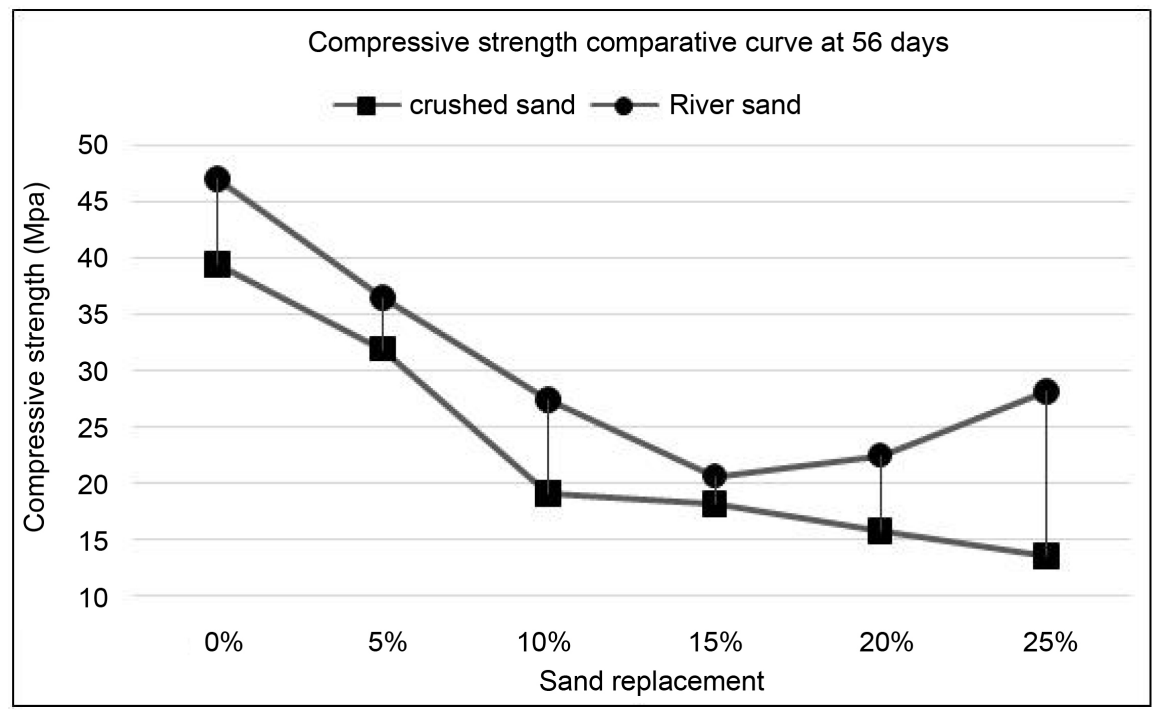

Figure 4. Compressive strength comparative curve at 56 days. 
and the mixture of wood ash and crushed gneiss are respectively $37 \mathrm{MPa}$ and $32.5 \mathrm{MPa}$ at 56 days. These values satisfied the strength requirements. Hence, $5 \%$ replacement of crushed gneiss with wood ash is suggested and could be benefit for mortar. The standard variation for all replacement percentage is of $8 \mathrm{MPa}$; which demonstrates that the strength development of mortar made with a mixture of WA and river sand is better and offers the highest mechanical performance. Then, the replacement of sand by wood ash is preferable with river sand which contains fewer fines than crushed gneiss. This result is due to the high quantity of fine contained in crushed gneiss + WA which it is confirmed by their fineness modulus.

\subsection{Density Test Result}

Figure 5 presents the evolution of densities of test-cubes.

Decreasing of density of mortar with the percentage of wood ash is observed. The highest density is obtained for control mortar (1.95 and 2.05 respectively for mortar made with river sand + WA and mortar made with crushed gneiss + WA). The lowest density is obtained at $25 \%$ of replacement (1.58 and 1.72 respectively for mortar made with river sand + WA and mortar made with crushed gneiss + WA). The difference between the highest and lowest values of density is 0.37 and 0.33 respectively for mortar made with river sand + WA and mortar made with crushed gneiss + WA). The difference between the density of mortar made with river sand + WA and the density mortar made with crushed gneiss + WA is 0.1 and 0.14 respectively at $0 \%$ and $25 \%$ of replacement. This difference is due to the fact that crushed gneiss is denser than river sand. In addition the density of mortar is also provided by calcium hydrates silicates gel, produce by cement hydration. In terms of compressive strength versus unit weight, with 5\% (river and crushed gneiss sand) and 25\% (river sand) the lightweight effect of mortar or cement by using incinerator bottom ash fine aggregates is unable to compensate the strength losses [5]. But mortar with these percentages of replacement can be use where compressive strength is less needed than lightness.

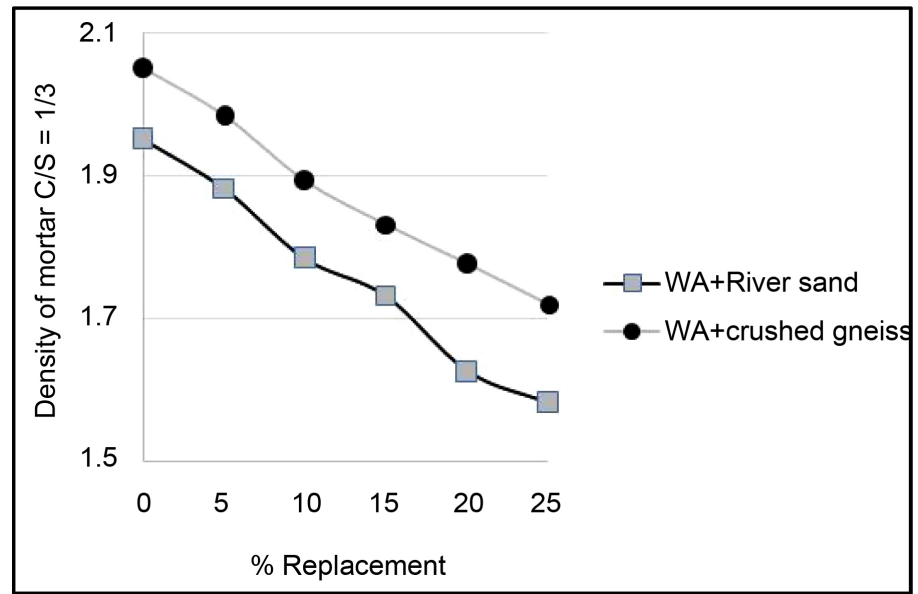

Figure 5. Evolution of densities of test-cubes. 


\section{Conclusions}

In this study the chemical and physical characteristic of wood ash, compressive strength and density of mortars made with WA were investigated. From the results of this work the following conclusions were made:

- The water requirement increases as wood ash volume increases.

- $5 \%$ replacement of cement with wood ash satisfied the strength requirements. Hence, $5 \%$ replacement of cement with wood ash is suggested and could be benefit for mortar.

- The compressive strength of mortar with $25 \% \mathrm{WA}+$ river sand presents an interesting value and then economic and environmental benefits could be obtained with $25 \%$ of replacement.

- Density decreases with an increasing WA content.

- The highest density of mortar is obtained with the mixture of crushed gneiss and wood ash.

- The replacement of sand by WA is preferable with river sand which contains fewer fines than crushed gneiss.

\section{References}

[1] Commission of the European Communities (2000) Establishing a List of Wastes Pursuant to Article 1(a) of Council Directive 75/442/EEC on Waste and Council Decision 94/904/EC, Establishing a List of Hazardous Waste Pursuant to Article 1(4) of Council Directive 91/689/EEC on Hazardous Waste. Official Journal of the European Communities L 226/3, Brussels.

[2] Hwang, C.L. (2007) Pozolana Concrete Using Manual. Sino Tech Engineering Consultants, Inc., Taiwan.

[3] Etiégni, L. and Campbel, A.G. (1991) Physical and Chemical Characterization of Wood Ash. Bioresource Technology, 37, 173-178. https://doi.org/10.1016/0960-8524(91)90207-Z

[4] Ottosen, L.M., Hansen, E.Ø., Jensen, P.E., Kirkelund, G.M. and Goltermann, P. (2016) Wood Ash Used as Partly Sand and/or Cement Replacement. Mortar International Journal of Sustainable Development and Planning, 11, 781-791. https://doi.org/10.2495/SDP-V11-N5-781-791

[5] Yang, M.-J., Wang, H.-Y. and Liang, C.-F. (2014) Study the Effects on Strengths of Cement Mortar When Using Incinerator Bottom Ash as Fine Aggregate. World Journal of Engineering and Technology, 2, 42-47. https://doi.org/10.4236/wjet.2014.23B007

[6] Batt, A.S. and Garg, A. (2017) Partial Replacement of Wood Ash with Ordinary Portland Cement and Foundry Sand as Fine Aggregate. Journal of Civil \& Environmental Engineering, 7, 2. https://doi.org/10.4172/2165-784X.1000272

[7] Boobala Krishnan, K.V., Vignesh, N., Kulandhai Antony, S., Mandira Adhikari, C. and Pagutharivu, N. (2017) Experimental Investigation on Partial Replacement of Cement by Wood Ash and Fine Aggregate by Wood Powder. South Asian Journal of Engineering and Technology, 3, 46-52.

[8] Chowdhury, S., Maniar, A. and Suganya, O.M. (2015) Strength Development in Concrete with Wood Ash Blended Cement and Use of Soft Computing Models to Predict Strength Parameters. Journal of Advanced Research, 6, 907-913. 
https://doi.org/10.1016/j.jare.2014.08.006

[9] Subramaniam, P., Subasinghe, K. and Keerthi Fonseka. W.R. (2015) Wood Ash as an Effective Raw Material for Concrete Blocks. International Journal of Science Technology \& Engineering, 4, No. 2.

[10] Sebastian, A., Manapurath, A.S., Balachandran, D. and Sebastian, D.M. (2016) Partial Replacement of Cement with Wood Ash. Ijste-International Journal of Science Technology \& Engineering, 2, No. 11.

[11] Chowdhury, S., Mishra, M. and Suganya, O. (2015) The Incorporation of Wood Waste Ash as a Partial Cement Replacement Material for Making Structural Grade Concrete: An Overview. Ain Shams Engineering Journal, 6, 429-437. https://doi.org/10.1016/j.asej.2014.11.005

[12] Yang, Z.F., Huddleston, J. and Brown, H. (2016) Effects of Wood Ash on Properties of Concrete and Flowable Fill. Journal of Materials Science and Chemical Engineering, 4, No. 7. https://doi.org/10.4236/msce.2016.47013

[13] ASTM D4326-13 (2013) Standard Test Method for Major and Minor Elements in Coal and Coke Ash by X-Ray Fluorescence. ASTM International, West Conshohocken. https://www.astm.org/

[14] ASTM C187-98 (1998) Standard Test Method for Amount of Water Required for Normal Consistency of Hydraulic Cement Paste. ASTM International, West Conshohocken.

[15] ASTM (2002) International Standard Test Method for Compressive Strength of Hydraulic Cement Mortars (Using 2-in. or [50-mm] Cube Specimens). ASTM International, West Conshohocken, 6. (Standard ASTM C 109)

[16] ASTM C188-17 (2017) Standard Test Method for Density of Hydraulic Cement. ASTM International, West Conshohocken.

[17] ASTM C204-17 (2017) Standard Test Methods for Fineness of Hydraulic Cement by Air-Permeability Apparatus. ASTM International, West Conshohocken. https://www.astm.org/

[18] NF P 18-540 (1997) Granulats.

[19] NF P 18-555 (1990) Granulats-Mesures des masses volumiques, coefficient d'absorption et teneur en eau des sables, Norme Française.

[20] NF P 18-598 (1991) Granulats-Equivalent de sable, Norme Française.

[21] ASTM C 618-94 (1994) American Standard for Testing and Materials, Standard Specification for Coal Fly Ash and Raw or Calcined Natural Pozzolan for Use in Concrete. ASTM International, West Conshohocken.

[22] Neville, A.M. (1995) Cementitious Materials of Different Types. Pearson Education Asia Pte. Ltd., Malaysia. 